\title{
COMPARATIVE PRODUCTION AND REPRODUCTION PERFORMANCES OF LOCAL AND MURRAH-CROSS BUFFALOES MANAGED BY SMALLHOLDER FARMERS IN BHUTAN
}

\author{
M.P. Timsina*, N.B. Tamang, D.B. Rai and M.N.A. Siddiky ${ }^{1}$ \\ National Dairy Development Centre, Yusipang, Ministry of Agriculture and Forests \\ Royal Govt. of Bhutan
}

\begin{abstract}
This study was undertaken to evaluate production and reproduction performances of local and Murrah-cross buffaloes managed by smallholder farmers of Bhutan. Data was collected from 80 buffalo farming households in three buffalo rearing districts (Samtse, Sarpang and Samdrupjongkhar) in the sub-tropical belts of Bhutan. There were 12 milking buffaloes per household and the duration of the field study was from $14-29$ December, 2014. Results indicated that average herd size is six buffaloes per household and are managed through open grazing with supplementary feeding but without proper housing. Study also revealed that genetic up-gradation of local buffalo population through introduction of Murrah breeding bulls and heifers has improved their productivity. Average daily milk yield of Murrah-cross buffalo is $5.9 \pm 0.18 \mathrm{l} /$ day/cow (Mean $\pm S E$ ) which is significantly higher $(p \leq 0.000)$ than that of local buffaloes yielding 2.6 $\pm 0.04 \mathrm{I} \mathrm{day}^{-1}$.

Murrah-cross buffaloes had better productive and reproductive efficiency than local buffaloes and have added advantage to buffalo farmers. Average age at first calving is $35.1 \pm 2.49$ months (Mean $\pm S D$ ) for Murrahcross buffaloes compared to $43.4 \pm 6.86$ months for local buffaloes. Similarly, lactation length for Murrah-cross buffaloes is $10.1 \pm 0.50$ month which is longer than local buffaloes ( $9.2 \pm 1.90$ month). Calving interval of $14.6 \pm 0.52$ months for Murrah-cross is lower than that of local buffaloes (17.4 \pm 1.01$)$.

Sale of fresh milk, butter and cheese from these animals contributed a major share of household income (54\%) and has helped to improve livelihoods of farmers despite major challenges faced: limited government support, shrinking of grazing areas and labour constraints. However, with intensified support, many farmers are enthusiastic to rear quality buffaloes that can be an opportunity to accelerate buffalo farming.
\end{abstract}

\footnotetext{
*Corresponding author email: timsinampdr2003@gmail.com

${ }^{1}$ Senior Program Officer, SAARC Agriculture Centre, Dhaka, Bangladesh
} 
Study concluded that owing to higher productivity of Murrah-cross buffaloes, it can be a viable dairy animal for subtropical belt of Bhutan. Regular exchange of breeding bulls, supply of quality heifers and artificial insemination facilities with adequate technical support are crucial for greater positive outcome of enhancing milk production in the country.

Keywords: Buffalo farming, Murrah- cross, Local buffaloes, Sub-

tropical belt, Bhutan

\section{INTRODUCTION}

Buffalo (Bubalus bubalis) farming is popular in south-east Asia and south Asia ( Banerjee, 1991). In Bhutan, buffaloes are reared only in warmer sub-tropical belt viz., Chukha, Samtse, Sarpang, S/Jongkhar, Tsirang and Dagana dzongkhag (district). The buffalo population in Bhutan was 28,000 heads in 1984 (FAO, 1984). But, over the last two and half decades, (Joshi, 2009) it was noted that buffalo number has gone down drastically and present population is reported to be about 800 heads (DoL, 2013).

Buffaloes in Bhutan are reared by small holder farmers for milk, meat, manure and for draft purpose. Although, multiple benefits are derived from Buffalo, farmers are not taking up Buffalo farming owing to inadequate policy support from the Govt. (Tamang et al., 2009). In an effort made to revamp buffalo farming, 17 heifers and 10 breeding bulls of Murrah cross breed were procured from India and distributed to farmers of buffalo farming areas in 2010, (MoAF, 2010). Until date, there is no reliable information available on their benefit to farmers which warrants scientific field study. In order to compare reproduction and production parameters of Murrah-cross and local buffaloes, understand effect of government breed improvement program and its impact on income and livelihood of farming communities and future interventions required to promote buffalo as an alternative dairy animal in the country, a detailed study on it was warranted. Accordingly, a comprehensive study was conducted with the objectives to:

- Compare reproductive and production performance of local (non-descriptive) and Murrah-cross buffaloes in Bhutanese environment

- Understand effect of crossbreeding program on productivity of village buffalo herd and its impact on income and livelihood of farming communities

- Suggest policy and technical support needed to accelerate buffalo farming in the country

\section{MATERIALS AND METHODS}

\section{Study area}

The study was carried out in four geogs (block) each of Sarpang, Samtse and SamdrupJongkhar Dzongkhags (district). The block and villages were selected based on buffalo population density and farmers involvement in buffalo farming. 


\section{Sampling techniques and data collection}

In total, 80 households possessing buffaloes within the selected blocks were purposively sampled. Semi-structured questionnaires were administered to collect data on reproduction and production parameter of Murrah-cross and local buffaloes and, impact of breed improvement on rural livelihoods and further intervention required. Morning and evening milk yield of Murrah-cross and local buffaloes under farmers 'management condition was measured using graduated measuring jug.

\section{Statistical Analysis}

- Quantitative variables such as production and reproduction parameters were entered in spread sheet. Mean, Standard Deviation and Standard Error (SE) was calculated and two Sample T- test was performed using Statistical Package for Social Science (SPSS) Version 22 to determine the significance level. version14.

- Qualitative data acquired through informal discussion were sorted and when appropriate, converted to a percentage

\section{RESULTS AND DISCUSSION}

\section{Buffalo management practices}

Buffaloes were found predominantly managed in free grazing system during the day and were tethered near the homestead at night without any shelter. It is evident that for small holder farmers owning $<3$ acres cultivable land, grazing on communal and fallow land (67\%) and forest and fringes (33\%) constituted major portion of fodder resources used by respondents. Nevertheless, farmers also fed native fodder, crop residues (straw) and home mixed local ration. Farmers believe that buffaloes are hardy animals, can thrive well in harsher conditions and are less susceptible to diseases compared to exotic cattle. Thus, with less input, farmers experienced that returns from buffaloes are better compared to other dairy animals.

\section{Buffalo breed types and herd dynamics}

Sampled farmers mostly reared local non-descript and Murrah-cross buffaloes. The existing Murrah- cross comprised of buffalo heifers and breeding bulls procured and supplied to farmers in 2010 and their off-springs. Average herd size was six buffaloes. Majority (21\%) of the buffaloes reared in the herd were Murrah-cross heifers and young bulls. The population of Murrah-cross calves was slightly more (12 $\%)$ compared to local calves (11\%). However, local buffalo heifers, young bulls and cows contributed to $42 \%$ and still continued to dominate the population of Murrahcross buffaloes (14\%).

\section{Reproduction parameters}

In the present study, age at first service for Murrah-cross buffaloes was $25.0 \pm 2.8$ months (Mean $\pm \mathrm{SD}$ ) and that of local buffaloes was $34.2 \pm 6.04$ months. Wangdi et al. (2014) reported similar finding that local buffaloes in Bhutan are bred 
for the first time at the age of 35.26 months. Similarly, average age at first calving was $35.1 \pm 2.49$ months (Mean $\pm \mathrm{SD}$ ) for Murrah-cross while $43.4 \pm 6.86$ months in local buffaloes (Table 1) indicating that reproduction in local buffaloes is irregular with greater variation as compared to crossbred buffaloes.

With added advantage of shorter calving interval of $14.6 \pm 0.52$ months as compared to $17.4 \pm 1.01$ months in local buffaloes, the Murrah-cross buffaloes can produce more claves in her life time. Lactation length for Murrah-cross buffaloes (10.1 \pm 0.50 months) was also longer than that of local buffaloes $(9.2 \pm 1.90)$. Hence, farmers harvested more milk and derived higher income for better livelihood.

\section{Production parameters}

Buffaloes were milked twice a day in early and mid lactation and once in the later phase. At least two teats were left for the calves to suckle till they attain 5-6 months and thereafter only one teat was allowed to be suckled but supplemented with green fodder and home cooked local feed.

Average daily milk yield measured in December 2014 for Murrah-cross buffalo was $5.9 \pm 0.18 \mathrm{l} / \mathrm{cow} /$ day (Mean $\pm \mathrm{SE}$ ) (table 2). Depending on the level of management, milk yield of Murrah-cross buffalo ranged from 4-10 1 day $^{-1}$. Milk yield of Murrah-cross buffaloes was found significantly higher $(\mathrm{p}<0.001)$ compared to local buffaloes which produces average of $2.6 \pm 0.041 /$ cow/day (Mean $\pm \mathrm{SE}$ ). However, these yields do not take into account the milk sucked by calf. Lesser variation in daily milk yield of local buffaloes indicated that they are more adapted than Murrah-cross buffaloes to adverse weather and management conditions.

This finding is in concurrence with Tamang et al. (2009) who reported yield of $2-5 \mathrm{~kg} / \mathrm{cow} /$ day and Wangdi et al. (2014) as $2.37 \pm 1.07 \mathrm{~kg} / \mathrm{cow} / \mathrm{day}$ for local Buffaloes in Bhutan. In similar mountain environment of Nepal, milk yield of Murrah-cross buffaloes and local buffaloes (in November) was reported to be $6.5 \pm 1.9$ 1 day $^{-1}$ and 2.471 day $^{-1}$ respectively (Hayashi et al., 2005). Thus, yield recorded in this study appeared to be typical of the ranges of similar genetic background.

\section{Income and livelihood source of the buffalo farming communities}

Buffaloes (especially from Murrah-cross) contributed a substantial portion of milk produced by sampled households. The sale of fresh milk, butter and cheese contributed maximum (54\%) of household annual income and has largely contributed to sustain their livelihoods while $19 \%$ was from sale of ginger (Figure 1). Besides, sale from Aracanut and excess food grains contributed to $11 \%$ and $8 \%$ of their annual income respectively. The Govt. intervention in breed improvement program in the recent years had immensely benefitted Buffalo rearing communities and buffalo farming is found to be becoming a lucrative venture to the farmers. 


\section{Prospects in Buffalo farming}

Despite key challenges such as shrinking grazing resources, and labour shortages, it was evident that majority of the respondents were very keen to intensify buffalo farming to sustain their livelihood. Their ability to thrive well and produce under harsh weather conditions with low quality forages and having higher disease resistivity than Jersey cows provided ample scope for farmers to accelerate buffalo production. There is also potential to diversify buffalo products: dried carabeef, and value added niche product- Mozzarella cheese. This could give new opportunity to diversify income from buffaloes and trap multi-facet benefits associated with buffalo farming.

\section{Policy and technical support to accelerate buffalo farming}

From the study, it is evident that $29 \%$ of the respondents desired for supply of quality Murrah-cross heifers/cows on cost sharing basis besides initiating community buffalo breeding scheme to meet requirement of breeding stock from within the herd. Likewise, $26 \%$ of respondents need continuous genetic up-gradation of local buffalo population with the introduction of AI services preferably using progeny tested Murrah semen, while $21 \%$ require support in fodder development. Similarly, support needed for construction of improved animal sheds attribute to (17\%) of the respondents.

\section{CONCLUSION}

Buffaloes are found to be an efficient feed converter and can be easily managed with by small and marginal farmers at minimal management interventions. Thus, considering land topography and farmers land holdings it is appropriate to promote buffalo farming with improved breed in the potential areas.

With better reproductive efficiency of Murrah-cross buffaloes reared in Bhutan, the Govt. intervention to improve buffalo breed through supply of improved heifers and breeding bulls have been very fruitful. Higher productivity of Murrahcross buffalos has substantially improved income and livelihoods of farmers.

Shorter age at first calving and calving interval, higher milk yield of Murrahcross buffalo make it a viable dairy animal for subtropical belt of Bhutan compared to local buffalo in terms of total productivity. Regular exchange of breeding bulls, supply of quality heifers and introduction of AI facilities with progeny tested Murrah semen can capitalize potentials of harnessing several advantages associated with buffalo farming. Therefore, it is imperative to have adequate policy support to intensify buffalo farming and stabilize buffalo population so as to bring about greater positive outcome of enhancing milk production in the country. 


\section{REFERENCES}

Banerjee G.C. 1991. Textbook of Animal Husbandry, 7th Edn, Oxford \& PBH Publications Pvt. Ltd

DoL. 2013. Livestock Statistics 2013, Department of Livestock (DoL), Thimphu

FAO, 1984. FAO Production Year Book, 38. Rome

Hayashi, Y., Shah, S., Shah, S.K. and Humagai, H.K. 2005. Dairy production and nutritional status of lactating buffalo and cattle in small scale farms in Terai, Nepal. Livestock Research for Rural Development, 17(6): 2005

Joshi, B. K. 2007. Consultancy Report, Village herd recording scheme and selective breeding of native domestic animals in Bhutan. RNRRC Jakar, Bhutan

MoAF, 2010. Mid-term Review Report of 10th Five Year Plan (2008-2013), Ministry of Agriculture and Forests (MoAF), Thimphu

Tamang, N.B, Sherpa, D.L, Sharma, B.N, Tshering, G, Thinley, G and Rai, D.B. 2009. Buffalo farming in Bhutan, vanishing before its full potential is explored. Journal of Renewable Natural Resources, Bhutan: 5: 82-93

Wangdi, J., Bhujel, P., Timsina, M.P. and Wangchuk, S. 2014. Performance of buffalo (Bubalus bubalis) under Bhutanese conditions, Global Journal of dairy farming and milk production, 2(2): 31-40 
Table 1. Reproductive parameters of buffaloes

\begin{tabular}{l|c|c|c|c}
\hline \multicolumn{1}{c}{$\begin{array}{c}\text { Reproductive } \\
\text { parameters }\end{array}$} & $\begin{array}{c}\text { Mean } \pm \text { SD } \\
\text { (Local } \\
\text { Buffaloes) }\end{array}$ & $\begin{array}{c}\text { Sample } \\
\text { size (n) }\end{array}$ & $\begin{array}{c}\text { Mean } \pm \text { SD } \\
\text { (Murrah-cross } \\
\text { buffaloes) }\end{array}$ & $\begin{array}{c}\text { Sample size } \\
\text { (n) }\end{array}$ \\
\hline $\begin{array}{l}\text { Age at first } \\
\text { service(months) }\end{array}$ & $34.2 \pm 6.04$ & 92 & $25.0 \pm 2.8$ & 38 \\
$\begin{array}{l}\text { Age at first } \\
\text { calving(months) }\end{array}$ & $43.4 \pm 6.86$ & 92 & $35.1 \pm 2.49$ & 38 \\
$\begin{array}{l}\text { Calving interval } \\
\text { (months) }\end{array}$ & $17.4 \pm 1.01$ & 88 & $14.6 \pm 0.52$ & 38 \\
$\begin{array}{l}\text { Lactation length } \\
\text { (Months) }\end{array}$ & $9.2 \pm 1.90$ & 88 & $10.1 \pm 0.50$ & 38 \\
\hline
\end{tabular}

* Figure are based on interview method and are farmer's best estimate

Table 2. Average daily milk yields for Murrah-cross and local buffaloes

(Mean \pm SEM)

\begin{tabular}{l|c|c|c}
\hline Buffalo type & N & Average yield $\left(\mathbf{l ~ d a y}^{-\mathbf{1}}\right)$ & SEM \\
\hline Murrah cross Buffalo & 15 & $5.9^{\mathrm{a}}$ & 0.18 \\
Local Buffalo & 18 & $2.6^{\mathrm{b}}$ & 0.04 \\
$p$-value & & 0.000 & \\
$\begin{array}{l}\text { a, b values with different superscript within a column are statistically different } \\
\text { Mean }\end{array}$
\end{tabular}

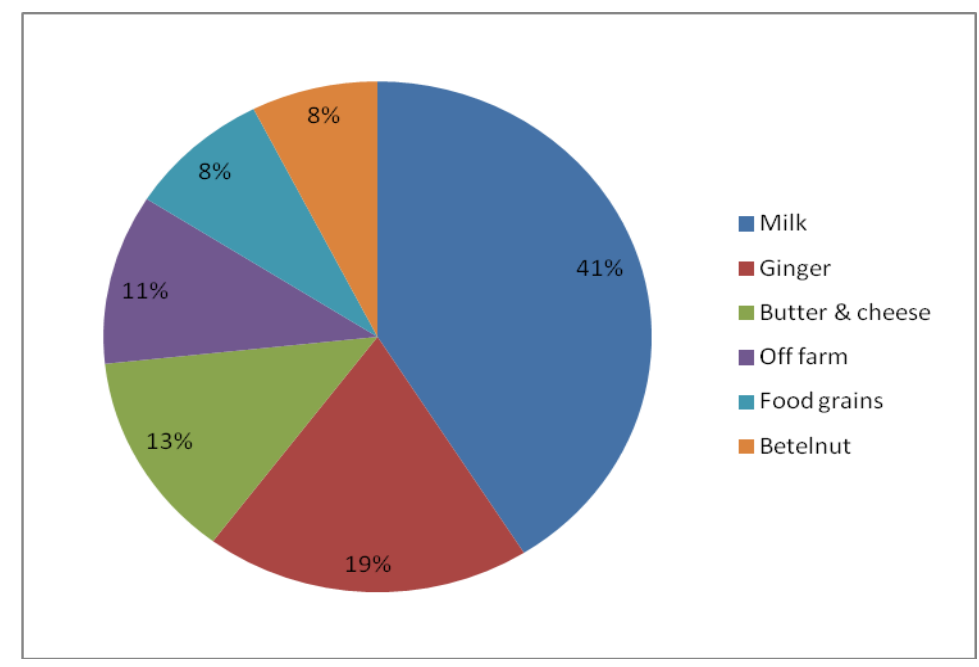

Figure 1. Household income sources 